\title{
Serum leptin and insulin concentrations in patients with insulinoma before and after surgery
}

Vera Popovic, Dragan Micic, S Danjanovic, S Zoric, M Djurovic, S Obradovic, M Petakov, Carlos Dieguez ${ }^{1}$ and $^{2}$ Felipe F Casanueva ${ }^{2}$

Institute of Endocrinology, University Clinical Center, Belgrade, Yugoslavia and Departments of ${ }^{1}$ Physiology and ${ }^{2}$ Medicine, Complejo Hospitalario de Santiago, Santiago de Compostela University, Santiago de Compostela, Spain

(Correspondence should be addressed to F F Casanueva, PO Box 563, E-15780 Santiago de Compostela, Spain)

\begin{abstract}
Inferential studies suggest that circulating insulin concentrations positively regulate leptin secretion by adipocytes. In humans, however, insulin requires prolonged periods of time, and relatively artificial set-ups before a relationship with leptin can be observed. In the present work, serum leptin concentrations were measured in five patients with insulinoma before and one month after surgery and in five control subjects matched by sex and body mass index (BMI).

The control subjects presented a mean serum leptin concentration of $6.7 \pm 1.5 \mu \mathrm{g} / \mathrm{l}$ and a BMI of $24.9 \pm 1.1$. The mean serum leptin concentration in patients with insulinoma was $11.8 \pm 3.1 \mu \mathrm{g} / \mathrm{l}$ $(P<0.05$ vs controls), with a BMI of $26.3 \pm 1.9$. After surgery, there was a non-significant reduction in BMI $(25.8 \pm 1.7)$, and a clear reduction in serum leptin concentration $(5.6 \pm 2.4 \mu \mathrm{g} / \mathrm{l}, P<0.05 \mathrm{vs}$ pre surgical values and no difference vs control subjects). The fasting area under the curve (AUC) of insulin concentration (in mU/l per $120 \mathrm{~min}$ ) before surgery was $14421 \pm 4981$ and after surgery was $1306 \pm 171(P<0.05)$. Before surgery, serum leptin concentrations significantly correlated with BMI $(r=0.71)$ and AUC of insulin $(r=0.82)$, a correlation that was lost after surgery.

In conclusion, serum leptin concentrations are significantly elevated in patients with chronically high insulin levels due to insulinoma. After surgical treatment and normalization of insulin values, leptin levels return to normal.
\end{abstract}

European Journal of Endocrinology 138 86-88

\section{Introduction}

In addition to its main role in regulating body weight, new important functions have recently been reported of the newly discovered hormone, leptin (1-6). However, the biological role as well as the regulation of leptin secretion by adipocytes are far from being completely understood. Data recently gathered has shown that leptin gene expression is influenced by insulin levels (7-9). Studies carried out on experimental animals (10-12) showed that insulin, both in vivo and in vitro, markedly increased leptin mRNA and leptin secretion, the effect becoming evident after a time-lag of less than $3 \mathrm{~h}$. In contrast, studies performed in vitro with human adipocytes, or in vivo have shown that short-term (less than $24 \mathrm{~h}$ ) exposure to insulin does not modify leptin gene expression while long-term exposure $(48-72 \mathrm{~h})$ leads to an increase in leptin mRNA and leptin secretion (13-15). These data suggest that in humans, as in the rat, insulin has a stimulatory effect on leptin secretion by the adipocytes, although this stimulation is somewhat delayed in its onset.
However, most of the data available in humans was obtained after performing euglycemic hyperinsulinemic clamps $(9,14)$ for a limited period of time, and so far there is no data available regarding the effects of chronically elevated insulin levels in the presence of counterregulatory mechanisms of glucose homeostasis. In order to examine the relationship between insulin levels and leptin secretion, leptin levels were studied in five patients with unregulated and chronically elevated levels of insulin due to insulinoma, both before and after surgery.

\section{Patients and methods}

Five patients with insulinoma ( 1 woman, 4 men, aged $50.8 \pm 8.7$ years) and five body mass index (BMI)- and sex-matched controls ( 1 woman, 4 men, aged $43.0 \pm$ 1.5 years) were studied. Diagnosis of insulinoma was made by the presence of the Whipple triad and confirmed by the detection of abnormally high plasma insulin levels with low glucose values under prolonged 
fasting, which was stopped in all cases after $24 \mathrm{~h}$ due to the presence of signs and symptoms alleviated by i.v. glucose. The presence of the insulin-secreting tumor was confirmed by histology after surgery. Blood samples were obtained early in the morning after a brief breakfast and none of the subjects was taking medication or drugs. All subjects provided informed consent and the study was approved by the Hospital Ethical Committee.

Insulin was measured by a commercial RIA kit (INEP, Belgrade, Yugoslavia) with intra- and interassay coefficients of variation of $6.1 \%$ and $13 \%$ respectively. Serum leptin levels were measured by radioimmunoassay (Linco Research, St Louis, MO, USA) with a limit of sensitivity of $0.5 \mu \mathrm{g} / \mathrm{l}$ and intra- and interassay coefficients of variation of $6.2 \%$ and $8.3 \%$ respectively. The area under the curve (AUC) for insulin was calculated by a trapezoidal method, after determinations every $15 \mathrm{~min}$ for $2 \mathrm{~h}$. A Wilcoxon test was used to compare values, and a regression analysis was performed. Results are expressed as means \pm s.E.M. and values of $P<0.05$ were considered significant.

\section{Results}

Control subjects presented a serum leptin concentration of $6.7 \pm 1.5 \mu \mathrm{g} / \mathrm{l}$ and a BMI (calculated as body weight in $\mathrm{kg}$ divided by the square of height in meters) of $24.9 \pm 1.1$. On the other hand, the mean serum leptin concentration in patients with insulinoma was $11.8 \pm 3.1 \mu \mathrm{g} / \mathrm{l}(P<0.05$ vs controls $)$, with a BMI of $26.3 \pm 1.9$ (Fig. 1). After surgery, a non-significant reduction in BMI was observed $(25.8 \pm 1.7)$ with a clear reduction in serum leptin concentrations of $5.6 \pm$ $2.4 \mu \mathrm{g} / \mathrm{l} \quad(P<0.05)$, not different from the control subjects. The fasting AUC of insulin concentration before surgery was $14421 \pm 4981 \mathrm{mU} / \mathrm{l}$ per $120 \mathrm{~min}$, and after surgery was $1306 \pm 171 \mathrm{mU} / \mathrm{l}$ per $120 \mathrm{~min}$ $(P<0.05)$. Before surgery, serum leptin concentrations

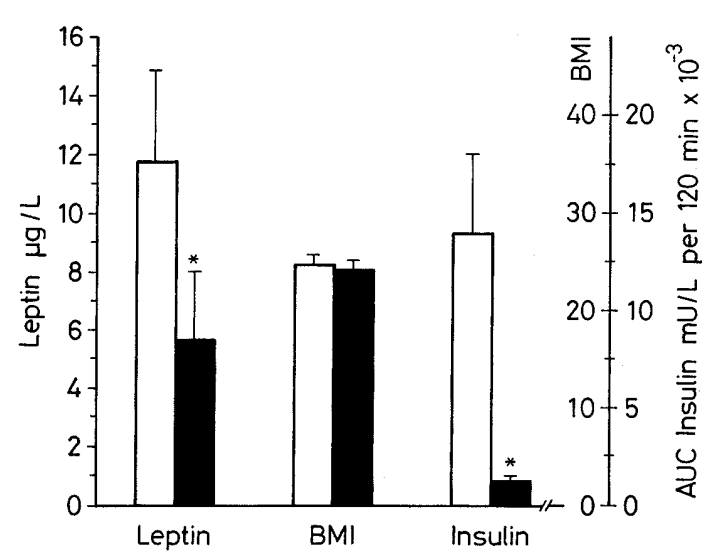

Figure 1 Serum leptin concentrations, AUC of serum insulin, and $\mathrm{BMI}$ in five patients with insulinoma before (open bars) and one month after (solid bars) surgical cure. Values are means \pm S.E. ${ }^{*} P<0.05$ vs pre-surgical values. significantly $(P<0.05)$ correlated with BMI $(r=0.71)$ and AUC of insulin $(r=0.82)$, a correlation that was lost after surgery.

\section{Discussion}

On the one hand, leptin seems to modulate insulin action (16), and on the other hand the close association between hyperinsulinemia and hyperleptinemia suggests that ob gene expression may be mediated by insulin (17). Although leptin and insulin evolve in parallel in fasting and overfeeding, the interrelationship is not at all simple, with controversial experimental results being reported $(18,19)$. Data gathered in humans supports a positive correlation between fasting concentrations of insulin and leptin, and a long-term stimulatory effect of insulin on leptin production in vivo and in vitro (14). However, the studies that demonstrated an effect of insulin on the regulation of leptin production required a 72-h hyperglycemic clamp, casting doubt regarding the final mechanism of this action, i.e. is it a direct one or a tropic effect of insulin plus glucose on the adipocyte?

In the present study, it has been shown that chronic endogenous hyperinsulinemia in patients with insulinoma tumors is significantly associated with enhanced leptin secretion, an action that is reversed after successful surgery. As no changes in BMI were observed after surgery, the clear-cut reduction in leptin serum concentrations probably reflects the reduction and normalization of insulin levels.

In conclusion serum leptin levels decrease after the successful cure of patients with endogenous chronic hyperinsulinemia due to insulinoma. This may suggest that insulin has a stimulatory role in regulating serum leptin levels. Further studies are needed in these patients in order to understand whether the insulin-mediated serum leptin increase could contribute to the development of insulin resistance.

\section{Acknowledgements}

This work was supported by grants from the Fondo de Investigacion Sanitaria, Spanish Ministry of Health, and Fundacion Española contra el Cancer. The expert technical work of Ms Mary Lage is gratefully acknowledged.

\section{References}

1 Zhang Y, Proenca R, Maffei M, Barone M, Leopold L \& Friedman JM. Positional cloning of the mouse obese gene and its human homologue. Nature 1994372 425-432.

2 Pelleymounter MA, Cullen MJ, Baker MB, Hecht R, Winters D, Boone $\mathrm{T} \&$ Collins F. Effects of the obese gene product on body weight regulation in ob/ob mice. Science $1995269540-$ 543.

3 Halaas JL, Gajiwala KS, Maffei M, Cohen SL, Chait BT, Rabinowitz D, Lallone RL, Burley SK \& Friedman JM. Weight-reducing effects of the plasma proteins encoded by the obese gene. Science 1995 $269543-546$. 
4 Considine RV, Sinha MK, Heiman ML, Kriauciunas A, Stephens TW, Nyce MR, Ohannesian JP, Marco CC. McKee LJ, Bauer TL \& Caro JF. Serum immunoreactive-leptin concentrations in normalweight and obese humans. New England Journal of Medicine 1995 $334292-295$.

5 Chehab FF, Lim ME \& Lu R. Correction of the sterility defect in homozygous obese female mice by treatment with the human recombinant leptin. Nature Genetics 199612 318-320.

6 Carro E, Señaris R, Considine RV, Casanueva FF \& Dieguez C. Regulation of in vivo growth hormone secretion by leptin. Endocrinology 1997138 2203-2206.

7 Reul B, Becker D, Rousseau V, Ongembs LN, Henquin JC \& Brichard SM. In vitro regulation of $\mathrm{OB}$ gene expression by hormones and nutrients in white adipose tissue. Diabetologia 199639 (Suppl 1) A 58, 212.

8 Laughlin G \& Yen SSC. Hypoleptinemia in women athletes: absence of a diurnal rhythm with amenorrhea. Journal of Clinical Endocrinology and Metabolism 199782 318-321.

9 Dagogo-Jack S, Fanelli C, Paramore D, Brothers J \& Landt M. Plasma leptin and insulin relationship in obese and non-obese humans. Diabetes 199645 695-698.

10 Hardie LJ, Guilhot N \& Trayhurn P. Regulation of leptin production in cultured mature white adipocytes. Hormone and Metabolic Research 199628 685-689.

11 Saladin R, De Vos P, Guerre-Millo M, Leturque A, Girard J, Staels B \& Auwerx J. Transient increase in obese gene expression after food intake or insulin administration. Nature 1995377 527-529.

12 MacDougald OA, Hwang CS, Fan H \& Lane MD. Regulated expression of the obese gene product (leptin) in white adipose tissue and 3T3-L1 adipocytes. Proceedings of the National Academy of Sciences of the USA $1995929034-9037$.
13 Vidal H, Auboeuf D, De Vos P, Staels B, Riou JP, Auwerx J \& Laville M. The expression of ob gene is not acutely regulated by insulin and fasting in human abdominal subcutaneous adipose tissue. Journal of Clinical Investigation 199698 251-255.

14 Kolaczynski JW, Nyce MB, Considine RV, Boden G, Nolan JJ, Henry R, Mudaliar SR, Olefsky J \& Caro JF. Acute and chronic effect of insulin relationship in obese and non-obese humans. Diabetes 199645 699-701.

15 Malstrom R, Taskinen M, Karonen S \& Yki-Jarvinen H. Insulin increases plasma leptin concentrations in normal subjects and patients with NIDDM. Diabetologia 199639 993-996.

16 Cohen B, Novick D \& Rubinstein M. Modulation of insulin activities by leptin. Science 1996274 1185-1188.

17 Cusin I, Sainsbury A, Doyle P, Rohner-Jeanrenaud F \& Jeanrenaud $\mathrm{B}$. The ob gene and insulin. A relationship leading to clues to the understanding of obesity. Diabetes 199544 1467-1470.

18 Zhang B, Graziano MP, Doebber TW, Leibowitz MD, WhiteCarrington S, Szalkowski DM, Hey PJ, Wu M, Cullinan CA, Bailey P, Lollimann B, Frederich R, Flier JS, Strader CD \& Smith RG. Down regulation of the expression of the obese gene by an antidiabetic thiazolidinedione in zucker diabetic fatty rats and $\mathrm{db} / \mathrm{db}$ mice. Journal of Biological Chemistry 1996271 94559459.

19 Becker DJ, Ongemba LN, Brichard V, Henquin J \& Brichard SM. Diet- and diabetes-induced changes in ob gene expression in rat adipose tissue. FEBS Letters $1995371324-328$.

Received 7 July 1997

Accepted 26 August 1997 